\title{
On the morphological nature of Spanish adverbs ending in -mente ${ }^{1}$
}

SERGI TORNER

\begin{abstract}
The morphological status of adverbs ending in -mente in Spanish (-ly in English) has been the object of many studies and continues to be the subject of debate. The two main proposals regarding the morphology of these adverbs treat them as either compounds or derivatives as the result of suffixation, but both hypotheses present problems. In this study an analysis will be defended which treats -mente as a phrasal affix (cf. Zwicky 1987, Nevis 1985 and Miller 1992). The notion of phrasal affix has been used to describe clitics which, from a morphological standpoint, are similar to affixes but which, simultaneously manifest characteristics of independent words. The argument for analyzing -mente as a phrasal affix is based on both synchronic and diachronic data, including some similarities with object clitic pronouns.
\end{abstract}

\section{Introduction}

Perhaps there are few constructions as difficult to characterise in Romance languages as -mente adverbs (-ment in Fr., Cat., -mente in Ital.). Whatever aspect is examined, and irrespective of the perspective from which the analysis is undertaken, it seems that the behaviour of these units is never easy to describe.

1. The research presented in this paper was supported by the project "Las acepciones lexicográficas relacionadas con sentidos metonímicos y metafóricos de las voces: catalogación y propuesta para futuros diccionarios" (Spanish Ministery of Education and Culture, DGES, BFF2000-0834), P.I. Paz Battaner. A previous version was presented at the XXXI Simposio de la Sociedad Española de Lingüística, held in Almería on December 17-20, 2001; I am grateful to thank the audience there, as well as P. Battaner, J. M. Fontana, J. DeCesaris, and two anonymous reviewers for observations and suggestions. Finally, I would like to thank L. McNally for extensive discussion and detailed comments on previous drafts. 
One aspect regarding which there is still no consensus is that of their morphological status: perhaps it is in the morphology where the hybrid character of these adverbs is most evident. In fact, probably due to the history of these constructions, ${ }^{2}$ these adverbs constitute a rara avis, because they are not exactly compounds, nor do they correspond exactly to derivatives. In Spanish, the language on which our study focuses, the problem is even more complex given the peculiar behaviour -mente adverbs may have in co-ordinations. ${ }^{3}$

This study aims to provide an analysis of -mente adverbs in Spanish. To do this, I start from a review of the two main previous proposals (Section 2), which I will call the compound hypothesis and the derivation hypothesis. This review aims not only to present these proposals, but also to provide the data which will have to be taken into account in the following description. As will be argued neither of the proposals is fully satisfactory. I will defend an approach based on the notion of phrasal affix which resolves the outstanding problems. After introducing the notion of phrasal affix (Section 3), its relevance for Spanish is examined in relation to proclitic personal pronouns (Section 3.1). Subsequently (Section 3.2), the phrasal affix analysis of -mente is defended, supported by new data which are problematic for the compound analysis. The data, strictly synchronic, are then complemented with an examination of the history of the construction (Section 3.3), which provides new arguments for the analysis.

\section{State of the question}

Several proposals have been formulated regarding the morphology of the Spanish -mente adverbs. The debate basically revolves around two distinct possibilities: ${ }^{4}$ the -mente adverbs can be seen as compounds or as derivatives. Nevertheless, both hypotheses present problems, and an examination of the peculiar

2. The Latin construction from which -mente adverbs originate was a noun phrase, and in current adverbs some vestiges of the syntagmatic character of the construction, which probably experienced a process of grammaticalisation in vulgar Latin, still survive.

3. The co-ordinations of these adverbs do not have the same characteristics in all Romance languages. For example, in French it is never possible to elide -ment in either of the two adverbs, and in (normative) Catalan elision takes place in the second compound: rápidament $i$ silenciosa ('quickly and quiet(ly)'). Although, as one anonymous reviewer suggests, the equivalent of -mente adverbs in other Romance languages like Portuguese manifest the same peculiar behavior as that observed in Spanish, the present study focuses only on Spanish.

4. Although others have been considered. Kovacci (1999: 709-710) summarizes the different analyses that have been proposed regarding the morphological nature of the -mente adverbs. Besides the two I am considering, there are analyses which treat them as adverbialised noun phrases - Bello (1847), Lenz (1935), Alcina and Blecua (1975) - and as inflected adjectives in an adverbial case - Alarcos Llorach (1951) -; nevertheless, in this study I will not analyze these latter two hypotheses. 
behaviour of these adverbs seems to provide data both for and against both of them.

\subsection{The -mente adverbs as compounds}

Various versions of the compound hypothesis have been defended, among others, by Bello (1847), Hockett (1971), Seco (1972), Bosque (1987), Zagona (1990) and Kovacci (1999). The defenders of this hypothesis put forward the following data in its favour. Firstly, as is shown in (1), -mente can be elided in all the members of a co-ordination except the last:

$$
\begin{aligned}
& \text { Lo hice rápida y cuidadosamente } \\
& \text { it did-1sg quick and carefully } \\
& \text { 'I did it quickly and carefully' }
\end{aligned}
$$

The phenomenon, as Kovacci observes (1999: 709), also occurs with disjunctive co-ordination, and within comparatives:
a. Directa o indirectamente
direct or indirectly 'directly or indirectly'
b. Lo han resuelto tanto técnica como teóricamente it have-3pl solved both technical and theoretically 'They have solved it both technically and theoretically'

According to the argument, in Spanish it is never possible to elide suffixes, whatever type they may be. Thus, (3a) cannot mean 'tables and chairs' nor (3b) 'small table (mesita) and small chair (sillita)', and there is also no possibility of the derivational suffix -ble of (3c) taking scope over the two adjectives in the construction.
a. Inflectional suffixes
mesa $y$ sillas
table and chairs
b. Appreciative suffixes
mesa y sillita
table and small chair
c. Derivational suffixes
*un problema observa y analizable
a problem observe- and analysable

In contrast, similar behaviour to that shown by -mente adverbs in co-ordinated structures is possible in some types of compounds. In fact, as is shown by the 
different examples in (4), the co-ordination of endocentric compounds ${ }^{5}$ permits elision of the head of the first conjunct, which is cataphorically recovered in the second conjunct.
a. países centro y suramericanos
'Central and South American countries'
b. datos tanto macro como microeconómicos
'both macro- and micro-economic data'
c. pre y postpalatales
'pre- and post-palatals'

In the co-ordination of endocentric compounds, the element elided is always the head:

$$
\text { [Adj [N centro] [Adj - head } \emptyset] \text { ] y [Adj [N Sur] [Adj - head americano]] }
$$

For that reason, given the similarity between the two examples shown in (1) and (2) and the examples in (4), it has been suggested that the -mente adverbs are also endocentric compounds, in which -mente is the head of the adverb, since this is the element that may be omitted in the co-ordinations. In other words, it is proposed that these adverbs are compounds formed by an inflected adjective in the feminine form and the mente noun, which is the head, as shown in bracketed structures in (6) and in (7):

$$
\begin{aligned}
& \text { [Adv [Adj Adj-fem] [N-head mente] ] } \\
& \text { [Adv [Adj directa] [N - head } \emptyset] \text { ] o [Adv [Adj indirecta] [N- head mente ] }
\end{aligned}
$$

The second argument in favour of the compound nature of the -mente adverbs is perhaps more substantial. It concerns the internal structure of the word: as will be shown in due course, -mente comes after the inflection of the adjective. Treating it as a derivational suffix would break a rule that seems to be general in the formation of words in Spanish: inflectional suffixes always follow derivational ones. Similarly, it is also useful to highlight the way the superlative of the adverb is formed, since the superlative affix precedes -mente, and does not seem to affect the derived adverb, according to Saporta (1990: 181). That is, although some morphologically simple Spanish adverbs can appear in

5. Although the studies examining these types of examples treat them as endocentric compounds, they are in fact difficult cases to classify, since the first parts could be considered as prefixes. The fact that elision is only possible in examples close to prefixation casts still more doubt on the compound analysis of -mente adverbs, where under no circumstances could the elided material be considered a prefix. 
superlative form (lejísimos 'very far'), the only way to put a -mente adverb in the superlative is to form the adverb from an adjective in the superlative:

$$
\begin{aligned}
& \text { fuertísimamente (as opposed to *fuertementísimo) } \\
& \text { 'very strongly' }
\end{aligned}
$$

Finally, there is a third argument that seems to support identifying -mente adverbs with compounds: their accentual properties. As has been frequently observed in the literature, the -mente adverbs in Spanish have a double accentuation, as they maintain the accent on the adjectival base, despite the fact that -mente is tonic. In Spanish, derived words never have this accentual pattern; as is well known, they always have a single accent, either on the suffix, if it is tonic (e.g., -ción, -miento, -áceo), or on the base, when it is atonic (e.g., -ble). In contrast, it has been argued that there are cases of compounds with the possibility of double accentuation. These are called imperfect compounds, characterised by a weak cohesion between their components, manifesting itself (among other things) in their accentuation (e.g., épico-lírico or marxista-leninista).

Thus, the possibilities of elision in the co-ordinates, the place that -mente occupies in the adverb - after the inflection - and the accentual properties of the whole are considered evidence for analyzing these formations as compounds. Nevertheless, this hypothesis has two drawbacks. First, mente (with the meaning that interests us) is not an independent word in the language. Although subsequently (Section 3.3) I will return in more detail to this question, at the moment it is enough to state that this element originates from the Latin noun mens, mentis, which in Spanish has also provided the noun mente ('mind'). However, from a synchronic point of view it is difficult to argue that adverbial -mente and nominal mente are the same word, since the meaning of the adverbial mente - if it has a precise meaning - has no relation whatsoever to that of the noun.

In order to overcome this obstacle, it could be argued that in fact, the mente in -mente adverbs is not the noun mente but rather an adverb. Nevertheless, this seems unsatisfactory on at least two counts. On the one hand, as a word the adverbial -mente would have the peculiarity of not being able to appear independently in the language, nor can it combine with an affix to form a derived word, but rather would necessarily have to function as forming part of a compound. ${ }^{6}$

6. Something similar occurs with the Greco-Latin morphemes, whose morphological analysis is also problematic. Nevertheless, these formations have characteristics that clearly distinguish them from -mente:

(a) The process of incorporation into the language was different: these are loaned expressions introduced as technical terms or speciality terms, which only later are extended to the general language;

(b) They have a stable meaning, which is maintained in all their occurrences - although some 
On the other hand, the question would remain as to what its meaning was. In fact, it does not seem that -mente has a stable meaning on all the occasions that it intervenes in the formation of an adverb. Given that it mainly intervenes in the formation of manner adverbs, it could be supposed that its meaning is 'in $X$ way' ( $X$ being the meaning of the adjective that enters into the formation). This explains, up to a point, the formation of all manner adverbs, but there are many other -mente adverbs that do not admit this paraphrase - for example, conjunctive (efectivamente 'indeed'), domain adverbs (matemáticamente 'mathematicallly' = from a mathematical point of view), speaker-oriented adverbs (francamente 'frankly'), etc. $-;^{7}$ these different readings make it rather difficult to establish a unitary meaning for -mente which allows the meaning of the construction to be explained compositionally.

Secondly, this hypothesis is also unsatisfactory if the internal structure of the word is considered. Note that the behaviour highlighted above concerning the possibilities of elision in co-ordinates leads us to consider the -mente adverbs as endocentric compounds with a nominal head. In the words of Val Álvaro (1999: 4766), "el núcleo es el constituyente en el que radican las posibilidades distribucionales y que determina el tipo de categoría de la construcción respectiva". ${ }^{8}$ From a semantic point of view, the meaning of endocentric compounds is obtained compositionally in that the element making up the head from the distributional point of view is also seen as doing so from the semantic point of view. Arguing, therefore, that -mente is the head of the adverb implies accepting that it determines both the distributional properties and the semantics of the word. In other words, according to this analysis, the -mente adverbs should be compound nouns, with a similar distribution to that of the noun that intervenes in the formation, which will also denote a notion related to mental states. However, neither of these two things occur, from which one can conclude that if -mente adverbs are compunds they cannot be endocentric compounds, since the noun - the element elided in the co-ordination - does not form the head from either a syntactic or semantic point of view. ${ }^{9}$ From all the above, I there-

of them are polysemic - and which also is the same meaning that the word had in Greek or Latin;

(c) They are much less productive than -mente;

(d) Many of them can be used indistinctly as prefixes or suffixes (e.g., litografía, aerolito; geografía, apogeo).

7. For a classification of the different types of adverbs in Spanish and the different paraphrases that they admit, see Kovacci (1999).

8. 'The head is the constituent in which the distributional possibilities lie and which determines the type of category of the respective construction'.

9. Zagona (1990) argues that the head of the compound is the adjective, and that the noun is an object argument. The noun occupies the position of the adjective's external argument. This hypothesis solves the problem of semantic selection satisfactorily to a certain extent. It 
fore conclude that -mente adverbs could only be exocentric compounds, but this would not provide the explanation of the possibility of omitting -mente in the first term of a co-ordination.

There is another problem regarding the morphological structure of the -mente adverbs if they are considered compounds formed by an adjective plus a noun mente: in Spanish, a compound formed from a noun and an adjective always follows the same pattern, which differs in several essential respects from the structure of the -mente adverbs. Summarising the observations of Val Álvaro (1999: 4813 et al), the noun-adjective compounds have the following characteristics in Spanish:

- Apart from some specific exceptions, such as buenaventura ('good' + 'look') or altiplanicie ('high' + 'plateau'), they are always endocentric compounds with an adjectival head. The category of the compound is adjectival, and it is the adjective that selects the noun semantically: cabizbajo $(<\operatorname{cab}(i) z$ 'head' + bajo 'low, down' ('downcast')), vasodilatador (< vaso 'vessel' + dilatador 'dilating').

- In all cases, the noun precedes the adjective: pelirrojo $(<$ pel- 'hair' + rojo 'red'), cejijunto (cej- 'eyebrow' + junto 'close' ('bushy-eyebrowed')).

○ It is the second component that bears any inflectional morphology, not the first: nortearagoneses (vs. *nortesaragonés), hispanohablantes (vs. *hispanoshablante).

In the -mente adverbs, in contrast, none of these characteristics are found, since (a) the order is always adjective followed by noun, (b) there is a vestige of the internal inflection - the adjective has a feminine termination -, although there is no inflection in the compound, given that the adverbs are invariable, and (c) the category of the compound is not adjectival ${ }^{10}$ (nor is it a noun) ${ }^{11}$ and there is no semantic selection of the noun by the adjective. In other words, if they are compounds, the -mente adverbs will be compounds formed by a noun and

is unsatisfactory, however, insofar as in order to explain why -mente can be omitted in the co-ordination, it has to be argued that -mente constitutes the head of the compound.

10. It is often held than adjectives and adverbs are subcategories of a single class (see for example González García 1997: 51-60 for a detailed discussion with respect to Spanish adverbs). On this view, the category of the word is still adjectival, in such a way that the resulting category is not in principle a problem for the compound analysis. Nevertheless, this hypothesis cannot save the compound analysis of -mente adverbs, because the compound analysis assumes that -mente is the head of the adverb, as it is the element elided in co-ordinations. If we postulate that the compound is an adjective we should posit that the head is the adjective. On the other hand, this hypothesis doesn't affect the (lexical or phrasal) derivative approach, because there exist affixes than don't change the category of the base in Spanish.

11. The fact that it is neither a noun nor an adjective is further proof that it is not an endocentric compound: by definition, only in exocentric compounds can the resulting category be different from that of its components, as occurs in the example sinvergüenza (sin- 'without' + vergüenza 'sense of shame' ('shameless person')). 
an adjective. Nevertheless, the adverb formed by this process will have none of the main characteristics that noun-adjective compounds have in Spanish; rather it will have an internal structure that is foreign to the language.

\subsection{The -mente adverbs as morphologically derived}

The analysis of -mente adverbs as derived by suffixation has been defended by, among others, Alarcos Llorach (1970 and 1994), Egea (1979), Karlsson (1981), Bosque (1989), Varela Ortega (1990), Miranda (1994), Rainer (1996) and Rodríguez Ramalle (1999). This analysis treats -mente as a derivational affix that is joined to adjective bases to form adverbs, which seems to agree with some notable aspects of the behaviour of these words. Firstly, the word internal syntactic and semantic relation between the adjective and -mente resembles that of affixation and not that of compounding. Briefly, Spanish adjective + noun compounds have two possible internal structures. One the one hand, in most Spanish adjective + noun compounds, as we have seen, the adjective is the head which selects the noun semantically (cf. Val Álvaro 1999: 4769 and 4772). In this case, when the adjective has just one argument, there is a modification relation involving the noun in which the noun doesn't saturate the external argument of the adjective but rather the adjective applies to another noun in the sentence (e.g., pelirrojo, cabizbajo or cejijunto). If the adjective has two arguments, the noun in the compound saturates one of the arguments of the adjective (e.g., vasodilatador). On the other hand, in the infrequent cases in which the noun is the head, it provides the referential index for the compound as a whole and saturates the external argument of the adjective (e.g., buenaventura or altiplanicie). ${ }^{12}$ Neither of these relations hold between -mente and the adjective.

In contrast, Spanish affixes select the base with they combine depending on features which Piera and Varela (1999: 4389-4393) call categorial, contextual and aspectual; all of these types of constraints are relevant for -mente adverbs. "Categorial" refers to the fact that affixes frequently select a base of a specific grammatical category. For example, -dad (-ity in English) only attaches to adjectives and -ble attaches to verbal bases. Clearly, we may postulate that -mente selects adjectives. ${ }^{13}$ "Contextual", in terms of Piera and Varela (1999), means

12. Zagona (1990) posits this latter structure for -mente adverbs - i.e., she assumes that -mente is the head and that it saturates the external argument of the adjective. Nevertheless, compounds such altiplanicie or buenaventura refer to a sort of planicie ('plateau') or ventura ('luck'), while rápidamente, abiertamente or completamente don't refer to a sort of mente ('mind').

13. Even though -mente doesn't combine with lexical bases, like Spanish derivational affixes, but with inflected words. It is for that reason, among others, that I propose an analysis in terms of phrasal derivation. See Section 3, below. 
that some affixes take into consideration the argument structure of the base they attach to. For example, the adjectival suffix -ble selects transitive verbal bases or, more infrequently, ergative verbal bases, but not intransitive ones. But more interestingly, the relation of the affix to the argument structure of its base is evident in the fact that some affixes inherit (part of) this argument structure. For example, the suffix -ción (-tion in English) forms nouns from verbs; these nouns inherit the internal object of the verb, which may be expressed with a de prepositional phrase:
a. destruir la ciudad
'destroy the city'
b. la destrucción de la ciudad
'the destruction of the city'

In this respect, -mente adverbs show a behaviour clearly similar to affixes, since most of them inherit some relevant aspects of the argument structure of the adjective. ${ }^{14}$ For example, if the adjective has an argument expressed by a PP, this same argument may appear with the adverb:
a. simultáneo a esa acción
'simultaneous to this action'
b. simultáneamente a esa acción
'simultaneously to this action'
a. contrario a lo esperado
'contrary as expected'
b. contrariamente a lo esperado
'contrarily as expected'

The possibility of expressing an argument of the adjective constitutes a strong argument against an analysis of -mente adverbs as compounds in which -mente is the head because, as Varela Ortega (1990: 100) asserts, "en el caso de los compuestos, el elemento léxico que no es núcleo no deja traslucir fuera de la construcción lexical superior sus posibilidades de expansion sintáctica". ${ }^{15}$

What is more, the class to which the resulting adverb belongs is predictable from the argument structure of the adjective to a large extent. Thus, for example, the intensional adjectives as presunto ('alleged') or supuesto ('presumed') modify the intension of the NP, and the adverbs which are formed from them

14. For a detailed discussion of the restrictions governing the inheritance of argument structure from the adjective base to which Spanish -mente adverbs are subject, see Bosque (1989: 133137).

15. Roughly, 'in compounds, the lexical element which is not the head is not able to project any of its combinatorial properties to the lexical item that contains it'. 
are intensional modifiers too. Likewise, if an adjective selects as its external argument an event noun to indicate its frequency (for example, frecuente 'frequent' or habitual 'habitual'), the adverb modifies an event argument, and indicates its frequency. Similarly, the agent oriented adverbs (like inteligentemente 'intelligently', estúpidamente 'stupidly', cuidadosamente 'carefully') are derived from adjectives that may modify a noun which denotes an action by an agent (as in respuesta inteligente 'intelligent answer', which indicates that the manner in which the answer is given is intelligent). So, in sum, the semantic restrictions that -mente adverbs impose on their arguments are inherited from the semantic restrictions that the adjective base imposes on its arguments. Note that if we assume (as Zagona 1990 does) that -mente adverbs are compounds with a nominal head, and that -mente saturates the external argument of the adjective, we cannot explain the fact that this inheritance takes place.

Finally, Piera and Varela use "aspectual" to refer to the fact that there are some affixes that select bases with an specific lexical aspect. For example, they note (1990: 4392) that Spanish prefixes $a$ - and $e n$ - cannot combine with telic verbs, as in ungrammatical forms *a-/en-encontrar, *a-/en-nacer, *a-/enromper. In this sense, -mente adverbs again behave like derivational affixes: as Varela Ortega (1990: 84) argues, the constraints which some Spanish adjectives show in the formation of -mente adverbs is due to aspect:

La diferencia entre los adjetivos que admiten -mente y los que no lo admiten reside en una distinción de carácter aspectual. Los adjetivos que proyectan el aspecto perfectivo [...] serán los candidatos potenciales a la advervialización. ${ }^{16}$

In sum, the constraints that -mente imposes on the adjectives with which it combines are those characteristic of Spanish derivational affixes.

A second argument for analysing -mente as a derivational affix comes from the nonexistence of -mente as an independent word in Spanish (since there is no synchronic relation with mente 'mind'). If -mente always appears attached to an adjective, it seems plausible to assume that it is a bound morpheme that necessarily attaches to its host.

Thirdly, the semantics of -mente discussed above is characteristic of some Spanish derivational affixes. Whereas in adjective + noun compounds, the noun has a clearly identifiable meaning - which is the meaning of the noun as independent word -, it is quite usual that there exists a vagueness in the meaning of derivational affixes. Typically, these affixes combine a grammatical meaning, mainly corresponding to the category and the semantic class of derived word, and a diffuse lexical meaning (see Pena 1999: 4322-4324). Sometimes, this

16. 'The difference between adjectives which accept -mente and those which do not accept it lies in a distinction of an aspectual nature. Those adjectives which project telic aspect [...] will be potential candidates to adverbialization'. 
lexical meaning is quite stable (for example, -nte (-ant in English) forms nouns that designate an agent), but often this lexical meaning is less specific (as in re-, that may mean 'repetition of an action' (rehacer 'to do again'), 'iteration' (redoble 'roll of a drum'), 'location' (rebotica 'backroom'), 'emphasis' (rebonito 'very nice'), among others senses). In this sense, -mente, which sometimes means 'in a X manner' but on other occasions seems to do nothing but convert an adjective into an adverb, clearly behaves like a derivational affix.

Fourthly, hypothesising that -mente is a suffix explains the fact that the resulting category of the word is neither an adjective nor a noun since there are many suffixes in Spanish which select bases of a specific grammatical category to form words of a distinct category - for example, -dad (-ity in English) only creates nouns from adjectives and -ble forms adjectives from verbal bases. It is quite natural on this analysis that -mente should form adverbs from adjectives.

Finally, the productivity of the process is also an argument in favour of this analysis. As is known, the formation of -mente adverbs is a highly productive process in Spanish - with the exception of some relational adjectives, all adjectives can be made into adverbs in -mente.$-{ }^{17}$ Productivity has been largely discussed in literature (see for example Aronoff and Anshen 1998), and although the concept of productivity in morphology is controversial because there are possible but not existing words, in Spanish compounding is often constrained by many kinds of restrictions, while some derivative affixes typically has a much higher productivity.

Thus, the data provide strong morphological, semantic and syntactic arguments in favour of a derivational suffix analysis. However, the three types of facts discussed in the preceding section which support the compound analysis seem to present insoluble problems for the affixation analysis: -mente always appears after the inflection of the adjective and can be omitted in co-ordinates and, moreover, the adverb preserves a double accentuation. In Spanish, as I have observed above, words formed by morphological derivation never show this behaviour. ${ }^{18}$

17. Egea (1979), partially reproduced in Egea (1993), provides a detailed study of the restriction that can be observed in the formation of adverbs of this type. Some clarifications of his description can be found in Kovacci (1999: 710-711).

18. There have been attempts to solve some of these problems within a lexical derivational analysis. For example, Villalva (2000: 117-121) presents a hypothesis that claims that the basis for affixational word formation may be a word. Her analysis, which however does not resolve the problem of co-ordinations with elision, would explain the appearance of affix after inflection and the double accentuation. However, this analysis is only suggested but not developed for -mente adverbs, for which she establishes a parallelism with a Portuguese construction which is analysed in detail, the Z-evaluative suffixation (anelzinho 'little ring' vs. aneizinhos 'little rings') which presents a suffix after an inflected word. Nevertheless, in Spanish this proposal seems difficult to justify since there are no other cases in which a derivational affix follows an inflectional mark. 
In sum, it can be stated that the construction analysed here is apparently a hybrid of derivation and compounding, since it shares characteristics of both types of word formation processes. On the one hand, -mente is very similar to an affix: the restrictions imposed on the adjective with which it will form an adverb and the meaning that the whole has follow the patterns of suffixation. On the other hand, however, if other characteristics of the adverb formed from -mente are examined, the conclusion must be reached that it is a compound, despite the fact that the internal structure of the adverb does not correspond to the usual structure of Spanish compounds.

\section{The -mente adverbs as the result of phrasal affixation}

Our proposal consists of approaching -mente as a phrasal affix. The concept of phrasal affix was originally proposed by Nevis (1985) in a study of the Saxon genitive and certain clitics in Finnish; his conclusions were revised by Zwicky (1987) and later, the same concepts were taken up again in other studies that examined the particular behaviour of some clitics in different languages (see, e.g., Miller 1991 and 1992). Although there are some differences in formalisation and in the list of units that can be treated as phrasal affixes ${ }^{19}$, all these studies coincide in applying this notion to a series of morphemes that have certain affixal properties but have also a syntactic behaviour partially similar to that of independent words.

On the one hand phrasal affixes have some or all of the following properties characteristic of affixes: ${ }^{20}$

(a) They attach to a host, unlike words; that is, they are bound morphemes.

(b) They occur in a fixed order, and this order is usually different from that of the corresponding full phrases.

(c) They show arbitrary gaps.

(d) Their phonological shape can be affected by the phonology of the stem or of other affixes with which they combine.

In short, they are not morphophonologically or syntactically independent units; thus, we must conclude that the units under consideration are morphologically

19. For a detailed discussion of the formal implementation of phrasal affixation as well as evidence that distinguishes phrasal affixation from lexical affixation, see Miller (1992: Chapter 4).

20. The studies on phrasal affixation usually examine particles that have been treated as postlexical clitics in the literature. For this reason they generally refer to six criteria proposed by Zwicky and Pullum (1983: 504) to distinguish between (lexical or phrasal) affixes from postlexical clitics, some of which coincide with the properties that I have listed. Nevertheless, I will not discuss these criteria exhaustively because most of them are not relevant for derivational affixes. 
affixes. Nevertheless, on the other hand, they may have some proprieties characteristic of words. Among these the most important are:

(a) They may have wide scope over co-ordination.

(b) They show so-called "promiscuous attachment", i.e., they can attach to words of various categories.

To reconcile this contradictory behaviour, the phrasal affix approach assumes that these units are bound morphemes - i.e., they are morphological affixes -, but instead of combining with lexical bases to form words in the lexicon, they combine with words or phrases to form phrases.

This approach has been most prominently applied to the analysis of clitics - that is, units which lack phonological stress. For example, Miller (1991) proposes that determiners in French are inflectional affixes that are attached not to a lexical base but to a noun phrase. Their affixal character is shown by their lack of syntactic independence, since they are necessarily bound morphemes. Nevertheless, their treatment in the lexical component is made difficult since they do not appear obligatorily next to the head (as occurs with the inflectional morphemes associated with nouns), but always occupying the first position of the phrase, attach to the word, independently of its grammatical category (i.e., they have promiscuous attachment). Furthermore, they possess other characteristics that show their attachment is not produced in the lexicon. For example, they fuse with other elements in the sentence $(d e+l e$ is produced as $d u$ or $\grave{a}+$ $l e$ as $a u$ ) or they may have, under certain restrictions, wide scope over noun coordination (for example, mon ami fidèle et collègue efficace ('my loyal friend and efficient colleague')).

My proposal extends this analysis to adverbial formation in -mente, ${ }^{21}$ even though -mente is not a clitic (since it has a tonic accent) and has a distinct morpho-syntactic-semantic nature from that of the morphemes that have been analysed as phrasal affixes. Because of this distinct morpho-syntactic-semantic nature, -mente does not possess most of the affixal properties listed above. However, the data previously presented are easily explainable if we assume that

21. From a theoretical point of view, this hypothesis may be controversial in that it appears not to respect a general principle, commonly accepted in linguistic theory, known as the "lexical integrity hypothesis", which argues for a radical separation between the lexical component, where the process of word formation is undertaken, and the syntactic component, which functions with already formed words. This principle, formulated very clearly in Chomsky (1970), has been lengthily debated in the literature. In Spanish, and in relation to the subject I am concerned with here, the question has been raised by Bosque (1987), in order to defend the argument that -mente adverbs are compounds. If we assume lexical integrity, it is not possible to propose word formation processes that function at a syntactic level. Obviously, if the analysis in this paper is correct, a strong version of lexical integrity cannot be maintained. 
-mente is a derivational phrasal affix which combines with adjective phrases. ${ }^{22}$ In fact, the data outlined above supports this hypothesis, given that -mente presents the hybrid behaviour between word and bound morpheme that is characteristic of phrasal affixes. On the one hand, we find in -mente most of the properties of derivational affixes. First, to assume that -mente is a (phrasal) derivational affix enables us to resolve the problem of category resulting from the process of formation: it is a derivational affix which derives adverbs from adjectives. Second, if -mente is an affix there is no need to explain why -mente does not exist as an independent word in the language. Third, we can explain the internal structure of the word, because as we have seen the word formation process involving -mente adverbs is subject to the semantic constraints characteristic of derivation in Spanish. On the other hand, if we assume that -mente is a phrasal affix which combines with an adjective phrase we can explain why the attachment is produced after inflection - it doesn't combine with an adjective lexical base on the lexicon but with an adjective phrase in the syntax - and why it may be omitted in co-ordination - it may combine with a phrase made up of a co-ordination of adjectives.

I now turn to the details of the analysis. First, I will argue that the positing of phrasal affix in Spanish is independently motivated by the behaviour of object clitics. Second, I will show how the phrasal affix analysis accounts for the data discussed earlier in the paper. And finally, I present diachronic data which lend additional support to the proposed analysis.

\subsection{Independent evidence for phrasal affixation in Spanish: Object clitics}

The first question arising from the hypothesis defended here is whether Spanish possesses other phrasal affixes, or, in other words, if it is possible to posit the existence of phrasal affixation in Spanish independently of the analysis that I propose for -mente adverbs. I believe that the behaviour of proclitic pronouns enable us to argue for an analysis of these elements in such terms, since they have some characteristics that make their full identification with affixes and words difficult.

In this section I will argue in favour of the phrasal affix nature of proclitic pronouns in Spanish, and thus prove that phrasal affixation is not a mechanism

22. Despite the fact that no existing studies have looked in-depth into the possibility of considering derivational morphemes or morphemes with a tonic accentual nature as phrasal affixes, there are some proposals to be found in this direction. For example Miller (1992: 139), suggests that "there are a number of derivational affixes which are good candidates for phrasal affix status. Among these, one can mention the Spanish suffix -mente, and the corresponding Old French suffix -ment, deriving adverbs from adjectives and the French suffix -ième deriving ordinal numerals from cardinal numerals", although he does not explicitly develop these suggestions. 
unknown to Spanish. Although the argumentation will take into account much data not directly relevant for -mente adverbs, I will discus the facts in some detail because they constitute a fundamental step in my argumentation: if I can show that phrasal affixation is a process which may be found in Spanish, nothing prevents us from extending this analysis to -mente adverbs.

The (quasi-)affix character of Spanish clitic pronouns was already observed in traditional grammar. As O. Fernández explains (1999: 1255-1258), object clitics present many characteristics similar to those of affixes. Some of them are the result of their atonic accentual status: they depend phonologically on the verb with which they appear and cannot form part of a co-ordination or be focalised - i.e., they are bound morphemes. Others, in contrast, are not the result of this atonic character: clitics are specialised with respect to the class of word to which they are attached, are combined in a strict order, and form morphological units, as is shown by the impossibility of a proclitic and enclitic affecting the same verb:

$$
\begin{aligned}
& \text { a. nos lo dijo } \\
& \text { to us it said-3sg } \\
& \text { b. *nos díjolo } \\
& \text { to us said-3sg-it }
\end{aligned}
$$

The affixal nature of Spanish objects pronouns is also shown by the fact that their phonological shape is sensitive to context, as seen in the phonological process of concealment known as the spurious $s e$ : the dative clitic $l e(s)$ becomes $s e$ in contact with the accusative clitic $l o(s)$ or $l a(s))$ :

$$
\begin{array}{lll}
\text { a. } & \text { le dije esto } \\
& \text { to him } & \text { said-1sg this thing } \\
\text { b. } & \text { se } & \text { lo dije } \\
& \text { to him } & \text { it said-1sg }
\end{array}
$$

Yet another sign that clitics are like affixes is the fact that they sometimes reduplicate an explicit complement:

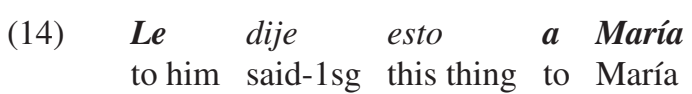

Thus there are significant data that lead us to treat Spanish clitic pronouns as affixes. This is unproblematic in the case of enclitic pronouns, which lake the syntactic properties characteristic of words and which induce word-level phonological processes. ${ }^{23}$ Nevertheless, there are greater difficulties in the treat-

23. In fact, unlike proclitic pronouns, verbal enclitics trigger phonological processes on the base which also argue for their treatment as lexical affixes. For example vayámonos (not *vayámosnos) or amaos (not *amados). 
ment of proclitic pronouns as lexical affixes because of their syntactic properties. Bosque (1987), for example, observes that, unlike enclitics, proclitics can be associated with more than one verb in a co-ordination:

$$
\begin{aligned}
& \text { a. lo [lei y corregi }] \\
& \text { it read-1sg and corrected-1sg } \\
& \text { 'I read and corrected it' } \\
& \text { b. *[leed y corregid] lo } \\
& \text { read and correct it it }
\end{aligned}
$$

In other words, as Bosque states (1987: 88), "la enclisis afecta a una sola palabra mientras que la proclisis afecta a una proyección sintagmática". ${ }^{24}$ This possibility clearly distances the proclitic pronouns from lexical affixes, since the possibility of taking scope over a phrasal projection is not available to them, as is shown by the impossibility of (16): ${ }^{25}$

$$
\begin{array}{cll}
\text { *re[elaborar } & y & \text { editar } \\
\text { re-(elaborate } & \text { and } & \text { edit) }
\end{array}
$$

The contrast between (15a) and (16) arises because the derivational attachment of $r e$ - must necessarily be produced in the lexicon and not in the syntax; expressed another way, this affix operates on lexical bases and not on the phrase, which prevents a syntactic configuration such as that shown with the use of square brackets in (16). In contrast, (15a) shows that Spanish proclitic pronouns are units operating in syntax, although the other data mentioned above are characteristic of affixes. The option of analysing proclitics as phrasal affixes enables us to explain this data. The treatment is also in consonance with the same concept of phrasal affix, as conceived in the literature, since the possibility of having wide scope over co-ordinations has been argued to be one of the strongest criteria for distinguishing between phrasal affixes and lexical affixes (see Miller 1991: 3).

In sum, the data presented suggest that proclitics are units with a mixed nature, behaving in part as affixes and in part as independent words. I posit that the properties that these pronouns possess are the consequence of their being

24. 'Enclisis affects one single word whereas proclisis affects a syntagmatic projection'.

25. An anonymous reviewer suggests that in Portuguese sequences like o meu ex-marido e sócio ('my ex-husband and (ex-)partner') and a minha ex-professora e amiga ('my ex-teacher and (ex-)friend') may be ambiguous between a reading in which $e x$ - has scope over the two terms and another in which it affects only the first of them. Nevertheless, in Spanish it is never possible for a derivational affix to have wide scope over the two terms of a co-ordination; that is, in the equivalent Spanish examples mi exmarido y socio and mi exprofesora y amiga, the prefix $e x$ - affects only the first term (my ex-husband is still my partner, and my ex-teacher is still my friend). Notes that examples like pre-y postpalateles in (4) have been analyzed as compounds, not as prefixed words. 
phrasal affixes. ${ }^{26}$ If we admit this analysis for proclitic pronouns, nothing in principle should prevent us from extending it to other elements with a quasiaffixal status, especially when, as occurs in the case of the -mente adverbs, their behaviour compared is so similar.

However it is true that -mente doesn't possess all of the affixal properties typically associated with phrasal affixes. Although it is certainly a bound morpheme - in the sense that it cannot appear as independent word - and it occurs in a fixed rigid order with respect to its host, it doesn't posses any of the other properties. Nevertheless, as Miller (1992: 141) asserts, "absence of arbitrary gaps, morphophonological idiosyncrasies, and semantic idiosyncrasies does not make affixal status impossible". In fact, these properties are usually associated with phonological atonicity, which -mente doesn't possess, and with the status of the clitic as a verbal complement, which -mente is not. The next section examines the advantages of the phrasal affix approach to -mente adverbs.

\subsection{Synchronic evidence for the phrasal affix analysis}

If we accept that the phrasal affixation is not unknown in Spanish, we can now consider in detail whether this analysis is viable for -mente adverbs. In particular, we will now examine the data that supported the compound analysis to see whether the phrasal affix analysis fares better or worse with these facts.

I begin by observing, the data in favour of the compound analysis do not constitute a counterargument to the analysis defended here. On the one hand, the appearance of -mente after the inflectional morphology of the adjective is explained by its phrasal nature; in other words, the fact that -mente does not select lexical bases, but rather adjective phrases in which the adjectives are already inflected. ${ }^{27}$ On the other hand, it is this same phrasal nature which ex-

26. Miller (1992: Chapter 5) develops an in-depth study of French pronominal clitics as phrasal affixes. Although there are differences between the French and Spanish object pronouns, many of his conclusions are also applicable to Spanish. See too Riemsdijk (1995) and O'Connor (2002)

27. Another question that the hypothesis of phrasal affix would have to answer is why the adjective is inflected in the feminine form. That -mente appears after the inflection on the adjectival base follows from the fact that it is a phrasal affix. Nevertheless, nothing seems to force agreement of the adjective in the feminine form. The only explanation that seems plausible is that this agreement is nothing more than a simple historical vestige without any linguistic value: the fossilisation of the old agreement in the heart of the Latin noun phrase has become a trait of morpheme selection; just as enclitic pronouns can only be attached to certain forms of the verb conjugation, -mente selects adjectives in the feminine form. As Rainer states (1996: 87), "the feminine marker of the base adjective does not realise any feature of the morphosyntactic representation dominating the adverb nor participate in any other way in the syntax of the sentence which it is part of. It is simply due to a parochial requirement of the suffix -mente". 
plains why elision of the first element of a co-ordination is possible: as a phrasal affix, -mente has the possibility of attaching itself to an adjective phrase, and these can be formed by a co-ordination of adjectives.

Because elision in co-ordinations is one of the strongest arguments in favour of the compound analysis, I will examine it in some detail. The compound analysis posits that in co-ordinations of adverbs with elision, -mente is the head of an endocentric compound which is elided in its first occurrence and recovered cataphorically thanks to the full presence of the same element in the second conjunct, as shown in the bracketed analysis of (17a). The phrasal affix approach posits instead that, strictly speaking, there is no elision, but rather -mente attaches to an adjective phrase formed via co-ordination and produces a phrasal adverb, as shown in (17b): ${ }^{28}$

$$
\begin{aligned}
& \text { a. [Adv directa-0] o [Adv indirecta-mente }] \\
& \text { direct- } \emptyset \text { or indirect-ly } \\
& \text { b. [AdvP [AdjP directa o indirecta]-mente] } \\
& \text { direct or indirect-ly }
\end{aligned}
$$

In the analysis schematised in (17a), a parallelism is established between -mente adverbs and Spanish endocentric compounds, such as centro y suramericanos or pre y postpalatales shown in (4) above. For these, Bosque (1987: 95) suggests an analysis in which there is a co-ordination of adjectives, not a coordination of adjective phrases:

$$
\begin{aligned}
& \text { [Adj [Adj centro-0] y [Adj sur-americanos] ] } \\
& \text { Central- } \emptyset \text { and South-American }
\end{aligned}
$$

Coordination at the lexical level is crucial, according to Bosque (1987: 97), because the elided head must be bound by a binding element which is immediately dominated by the same node that immediately dominates the bindee. If Bosque's hypothesis is correct, we can explain why (19b) is not possible, even though (19a) is grammatical: the elided head cannot be bound by its binding element because that element is immediately dominated by a node ( $\mathrm{AdjP})$ that does not immediately dominated the bindee.

28. An anonymous reviewer of this paper suggests a third possible analysis for this kind of example. The reviewer observes that adjectives in Spanish sometimes have an adverbial distribution, as in hablar rápido ('to speak quickly') or hilar fino ('to split hairs', literally 'to spin finely'). For these adjectives a conversion operation has been assumed that, in the reviewer's opinion, could be extended to the first adjective in an elided co-ordination. However, as Bosque (1989: 130) points out, these adverbialized adjectives are constrained by a set of restrictions: first, they are fixed in the masculine singular form; second, there is a small list of units that can be used in this way; and third, excepting a few number of adverbs like rápido, they have a fixed order of appearance (they must immediately follow the verb). None of these restrictions affect co-ordinations of -mente adverbs. 

a. Debería hallarse más antepuesto o más pospuesto. should-3sg be more before-put or more after-put 'It should be put before or after'
b. *Debería hallase más ante- $\emptyset$ o más pospuesto.

To maintain the compound analysis the same relation between binder and bindee must hold in a co-ordination of -mente adverbs with elision. That is, Bosque must assume that (17a) is a co-ordination of adverbs, not a co-ordination of adverb phrases, since the cataphoric recovery must respect the conditions on binding:

$$
\text { [AdvP [Adv directa- } \emptyset] \text { o [Adv indirecta-mente }]
$$

This predicts that, parallel to what was obsserved in (19b), we should not find coordination of adverb phrases involving elision of -mente. However, this prediction is incorrect. Consider an example such as (21):

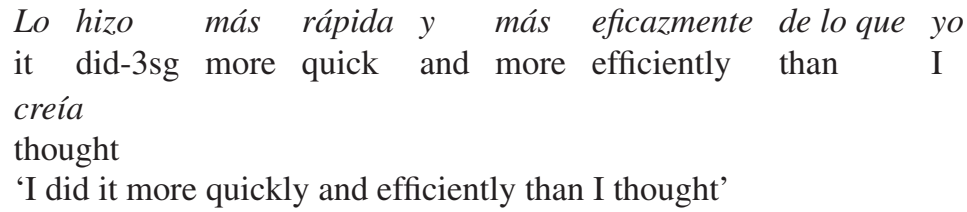

It must been noted that this analysis encounters a problem that is hard to resolve: to recover the elided head of the first compound it must be bound by a binding element inside a government environment. Nevertheless, the presence of the adverb of degree más in both elements of co-ordination clearly shows that there is not a co-ordination of adverbs but of adverb phrases.

In contrast, the acceptability of (21) follows straightforwardly if we assume that -mente attaches to adjective phrases, as in (22):

$$
\begin{array}{rlllll}
\text { [AdvP [AdjP } & \text { más rápida } & y & \text { más eficaz]mente] } \\
\text { more quick and more efficient-ly }
\end{array}
$$

A second set of data in support of our hypothesis is based on the frequency of use of the co-ordinate constructions. If -mente is a phrasal affix which combines with adjective phrases, we might expect a tendency for the affix to combine with coordinated adjectives rather than with two full adverbs, given that co-ordination of two adjectives forms an adjective phrase with which -mente may combine. According to the study by Karlsson (1981), elision is the only possibility that has been documented since the 16th century, which could support our thesis from a historical perspective. If elision were the only possibility nowadays, this would obviously be a strong argument for the phrasal affix analysis. Nevertheless, Karlsson does not cover modern Castilian in his analysis, 
Table 1. Co-ordinations of -mente adverbs in the corpus of the IULA

\begin{tabular}{lcc}
\hline Corpus & $\begin{array}{c}\text { Co-ordination } \\
\text { without elision }\end{array}$ & $\begin{array}{c}\text { Co-ordination } \\
\text { with elision }\end{array}$ \\
\hline $\begin{array}{l}\text { Journalistic texts } \\
\quad \text { No. of documents: } 47\end{array}$ & 1 & 43 \\
$\quad$ No. of words: $1,800,297$ & 1 & 35 \\
Environment & & \\
No. of documents: 45 & 1 & 109 \\
No. of words: 942,065 & & \\
Law & & \\
No. of documents: 122 & 3 & \\
No. of words: $2,082,850$ & & \\
Total & & \\
No. of documents: 214 & & \\
No. of words: $4,825,212$ & & \\
\hline
\end{tabular}

and it is clear that the two options are possible today. I have undertaken the research of a corpus of modern Spanish texts. Although the data obtained should be taken with the necessary caution, since I have not carried out an exhaustive study on a wide-ranging set of texts, the results clearly show a very strong statistical preference for elision, as the phrasal affix hypotesis would predict.

I carried out various searches on a textual corpus that has been elaborated in the Institut Universitari de Lingüística Aplicada (IULA) of the Universitat Pompeu Fabra. First, I collected data from a body of journalistic texts, which were supplemented with data obtained by consulting a body of technical texts, among which feature selected texts about the environment and legal texts. ${ }^{29}$ Looking through the results obtained from these corpora, which are shown in Table 1, the co-ordinate -mente adverbs have been identified when they appeared in the two full forms and when the first of the co-ordinate elements was elided. As can be seen, in practically all cases, co-ordination with elision was preferred. $^{30}$

29. For these last two types of text the Corpus Textual Especializado Plurilingüe has been used (see http://www.iula.upf.es). This corpus consists of written texts in five different languages (Catalan, Castilian, English, French and German) in the domains of economics, law, environment, medicine and computer science.

30. Very few of the co-ordinations with elisions are lexicalised co-ordinations (see below). Of the 187 cased documented, only 10 belong to total y absolutamente (all of them in legal documents) and 12 to única y exclusivamente (4 in each of the corpus consulted). 
With the goal of obtaining more representative results, these data were compared with a search on a corpus of oral texts. To do this, the Corpus de Referencia del Español Actual (CREA) of the Real Academia Española was used. ${ }^{31}$ The results of this search are 23 co-ordinations without elision and 63 coordinations with elision. It can be seen that the co-ordinations of -mente adverbs in oral texts do not show as clear a behavioural pattern as can be seen in written texts. Whereas it appears clear that in written language the elision of -mente on the first conjunct is a practically exclusive option, in oral language the difference between the use of both constructions is smaller, even though it is a fact that the co-ordinations with elision are still the most frequently used.

It is not an easy task, given that the set of data on which our study is based is relatively small, to explain this difference of use shown in the comparison between the two corpora consulted. Only by way of hypothesis can it be suggested that this difference of use is due to different characteristics of oral versus written language. Firstly, one of the characteristics of oral language is the use of diverse intensifying resources (see Briz 1998: 43 and 53-55); the results could be explained by appealing to this tendency towards intensification in oral language, given that the repetition of -mente provides an emphasis on each word. Secondly, elision could be associated with greater planning, as occurs in written language, which is closely linked to a greater syntactic complexity: we want hypothesise that the attachment that affects a phrase involves a greater syntactic complexity than the co-ordination of two adverbs. Furthermore, for elision to be produced, it is necessary for the speaker to plan his or her discourse in advance, and to have previously decided that after the first adverb s/he will use a second adverb in co-ordination. In other words, it is necessary for the decisions about the syntax of the discourse to run on line. In this way, therefore, the repetition of -mente could be the result of insufficient planning or a change of strategy by the speaker when s/he has already started their utterance.

Despite these differences between the oral and written forms, and although they are aspects in which future investigations should probe further, the corpus data lend support to the theory defended by this study. The rule of elision in co-ordinates is practically exclusive in the written form, and in the oral form, which both options are possible, there is a difference in favour of elision.

The phrasal analysis of -mente adverbs doesn't predict that co-ordination is obligatory: given a co-ordination of two adjectives, we must postulate that there is a co-ordination of two adjective phrases, since there are two possible

31. Two filters have been established over the huge amount of material of this corpus: one concerning the medium - searches have been made only on oral texts - and another geographical - within Spain -. The CREA was not used for the written texts because at the time this research was conduced the search tool did not permit searches that resulted in a high number of hits. 
hosts with which -mente can combine. Nonetheless, we might at less partly explain the preference for elision in terms of structural simplicity: given a coordination of two lexical units $\mathrm{X}^{\circ}$ of the same category, we may suppose that each unit is the head of an $\mathrm{X}$ phrase, in such a way that the co-ordination is made between phrases, or we may suppose that the co-ordination affects lexical items, in such a way that there is a unique co-ordinated head for a unique $\mathrm{X}$ phrase. The last possibility involves a greater structural simplicity, because the former possibility entails that each lexical unit generates a phrase. In this sense, if we assume that -mente is a phrasal affix, the preference for elision in coordinations of adverbs is a natural consequence of the greater simplicity of the syntactic structure associated with elision. Since the compound analysis always postulates a co-ordination of adverbs, independently of whether there is elision or not, nothing explains on this approach why there is a preference for elision.

There is a third fact that also provides support for the proposed analysis: lexicalisations of co-ordinated phrases with elision. The relevant cases are those in which the co-ordination of adverbs is formed from a lexicalised co-ordination of adjectives, or from a very frequent collocation of co-ordinated adjectives. If, as defended here, the attachment of the morpheme is phrasal, we predict that elision will be obligatory, because -mente attaches to a host that constitutes a lexical unit - even though it was originally formed by a co-ordination. This prediction is borne out: although such lexicalisations are not very common, there are some (for example, única y exclusivamente ('sole[ly] and exclusively'), lisa y llanamente ('plain[ly] and simply') or perhaps pura y simplemente ('pure[ly] and simply')). Observe the lack of naturalness of (23) and the ungrammaticality of (24): ${ }^{32}$

(23) ??Lo ha hecho únicamente y exclusivamente para que lo sepamos.

'He has done it solely and exclusively so that we realize it'

*Lisamente y llanamente, esto es imposible.

'Plainly and simply, this is impossible'

In fact, lisa y llanamente is a lexicalised expression formed from a co-ordination of adjectives which is lexicalised too: neither liso nor llano can be used separately with the meaning that they have in the lexicalised co-ordination liso $y$ llano, ${ }^{33}$ which has the meaning that appears in lisa y llanamente. So the ungrammaticality of (24) is correctly predicted on the phrasal affix analysis.

32. It must been noted that all of these -mente adverbs may be formed in Spanish: lisamente exists alongside as únicamente and puramente.

33. For example, both the Diccionario de la lengua Española edited by the Real Academia Española and the Diccionario del Español Actual by Seco et al. include this construction as a "locución adjetiva" ('lexicalised adjective phrase') in the definition of liso. 
Único y exclusivo is a collocation, but not a lexicalisation, so that (23) is possible but not natural. The existence of co-ordinations with obligatory elision like these is more easily explicable if it involves a process of derivation in which the affix -mente combines with a lexicalised co-ordinated host rather than one in which two -mentes combine individually with separate hosts, because the adjective co-ordination forms a lexical unit. In addition, the fact that in Spanish there are no lexicalised co-ordinations of -mente adverbs in which the two full forms appear is also significant.

Finally, the double accentuation of -mente adverbs is also compatible with the phrasal affix analysis. As Pensado (1999: 4441) explains, "el dominio del acento en español es la palabra". ${ }^{34}$ This means that a word can have only one accent. Apart from -mente adverbs, the only exceptions to this behaviour are the so called imperfect compounds. ${ }^{35}$ In these, the cohesion between the components is very weak, which means that from a morphological point of view they only partly behave as a single word. This lack of cohesion has three consequences that are relevant for the analysis of -mente adverbs:

- The morphological integrity of the compound is respected; that is, the compounding process never produces phonological alterations in the first element of the compound. Cf. pelirojo ( $<$ pel(o) 'hair' + rojo 'red' ('redhead')) or norvietnamita ( $<$ nor(te) 'North' + vietnamita 'Vietnamese'), with loss of phonological content in first element, versus the imperfect compound épicolírico (< épico 'epic' + lírico 'lyric'), which maintains the full form of the first element.

- We may find word-internal inflection. Examples of imperfect compounds are salón comedor ('sitting + dinning room'), which only has the plural salones comedor (internal inflection), and marxista-leninista ('Marxist-Leninist'), which has two possible plurals, both marxistas-leninistas (internal-final inflection) and marxista-leninistas (final inflection). In contrast, a non-imperfect compound such as lavacoches (lava 'wash (3th pers.)' + coches 'cars' ('carwasher')) never has internal inflection (*lavascoches).

- Each part of the compound may preserve its accent: in imperfect compounds like salón comedor there are always two accents, whereas in imperfect compounds like épico-lírico a variant with two accents co-exists with a variant with loss of accent in the first element.

The compound analysis of -mente adverbs entails that these adverbs are imperfect compounds too. The argumentation takes into consideration that these adverbs possess all the properties of imperfect compounds: they never produce phonological alteration of the first component (there is no process equivalent

34. "The domain of accent in Spanish is the word."

35. Also some cases of prefixation that in fact are close to this type of compounds. 
to what produces French savamment ( $<$ savant, -e 'wise') or prudemment $(<$ prudent, $-e$ 'cautious'), in which there is a change in the phonological content of the adjective); they have a vestige of internal inflection (the adjective is in feminine form); and they have two accents. Nevertheless, this analysis runs into the problem that Spanish imperfect compounds have a different internal structure than -mente adverbs: on one hand, they are always noun + noun or adjective + adjective compounds; on the other hand, from a semantic point of view they describe the union of two concepts, in such a way that a salón comedor is a room which is at the same time a salón ('sitting room') and a comedor ('dinning room'), and épico-lírico refers to everything that is epic or lyric, not to the intersection of those things that are epic and those that are lyric. In addition, Spanish imperfect compounds are always exocentric. ${ }^{36}$ In contrast, -mente adverbs have none of these characteristics, although they have a morphophonological behaviour similar to imperfect compounds.

The analysis defended here permits a different explanation of double accentuation that solves the problem of the internal structure of the adverb. Harris (1991: 118-119) explains that Spanish inflectional suffixes are always word final, so the feminine marker of adjective in -mente adverbs marks a word boundary. Therefore, "el sufijo adverbial -mente ejemplifica claramente el caso relativamente raro en que un sufijo se adjunta en el nivel de la palabra". ${ }^{37}$ The phrasal affix analysis assumes that -mente combines combines with words, not with derivational bases; that is why inflection precedes -mente. If we accept that the domain of accent assignment is the word, the phrasal affix analysis predicts that the adjective maintains its accent. ${ }^{38}$

\subsection{Historical evidence for the phrasal affix hypothesis}

Traditionally, it has been assumed that Spanish adverbs in -mente were the result of the grammaticalization of a process involving Latin mente (cf., e.g., Hopper and Traugott 1993: Chapter 5; Giacalone Ramat 1998: 120). As Kovacci summarises (1999: 708), ${ }^{39}$

36. Recall that the defenders of the compound analysis of -mente adverbs are committed to treating them as endocentric. See Section 2.1.

37. 'The -mente suffix shows clearly a relatively strange case in which a suffix combines in word level'.

38. The fact that -mente has tonic accent is unproblematic for a (lexical or phrasal) affix analysis, since in Spanish there are many derivational affixes which are tonic, such as -ción, -miento, $-a l$, etc.

39. An anonymous reviewer has suggested that the Latin noun phrase from which the Spanish construction originates was the object of a PP with an adverbial distribution (de bona mente). This is not correct: the Latin noun phrase was marked in ablative case, and this case marking made unnecessary the presence of a preposition to mark the function of the noun phrase. (See 
los adverbios en -mente del español se originan en la construcción sintáctica latina, de valor adverbial, formada por mente, ablativo del sustantivo femenino mens, mentis, 'mente, ánimo, intención', y un adjetivo concordado antepuesto. ${ }^{40}$

But this analysis appears to be incorrect because, as I will explain below, the construction originally involved a borrowing into Spanish which did not exist as an independent word. This casts doubt on the compound hypothesis.

The evolution of the Latin ablative mente ${ }^{41}$ intervening in the construction generated four variants that coexisted until the 13th century, all of them with diphthongisation of the Latin short $e$ : mientre, miente and the corresponding apocopated forms mientr and mient; of these four forms, the first is clearly the dominant one. It was not until the first half of the 13th century that two new forms appeared without diphthongisation, ment, which is undoubtedly a loan (probably from Aragonese or Catalan), and mente, which is a Castilinaized adaptation of -ment with the addition of an $-e$ by analogy with some apocopated forms ${ }^{42}$; during the second half of the century, these forms were extended in use, until becoming dominant in the 14th century, until, in the 15th century, mente pushed aside all the others. In other words, from a historical point of view, the current adverbial mente does not come directly from the Latin noun, but is a loan that replaced the patrimonial forms with diphthongisation.

This phenomenon acts as a counterargument to the compound hypothesis, especially if we take into account that the surviving -mente form, taken as a loan in the 13th century, did not then coincide with the noun, given that the only form known for this was miente, with regular diphthongisation of the $e$, until in the 17th century it took the current form as a refined expression of Latin (see $D C E C H$, s.v.). In other words, for nearly four hundred years Spanish had a process of adverbial formation from adjectives that used a form that did not exist as an independent word in the language, and only from the 17th century onwards have we seen the coincidence between the affix and noun on which the hypothesis of compounding is based.

Karlsson (1981: Chapter 3); for a discussion of de buena mente in Old Spanish, see Karlsson (1981: 96-97)).

40. "The -mente adverbs of Spanish originate in the Latin syntactic construction, of adverbial nature, formed by mente, ablative of the feminine noun mens, mentis, 'mind, mood, intention', and a preceding agreeing adjective."

41. What follows is a summary of the main conclusions of Karlsson's study (1981: Chapter 5), which I refer the reader to for a more detailed analysis of the question.

42. Karlsson (1981: Chapter 5) discusses in detail the arguments which demonstrate that these forms are loans in Spanish, and indicates which languages they are most probably loaned from. She concludes (Karlsson 1981: 100): "Whether ment was French or Provençal, Aragonese or Catalan, it was not an indigenous Castilian form. The forms in mente are, on the other hand, Castilianized versions of the borrowed forms in ment, that is, ment was interpreted as an apocopated form and the $-e$ was restored analogically". 
In the light of this phenomenon, it is more appropriate to propose that the patrimonial forms with diphthongs, independently of their classification (word or affix), were replaced by a foreign term which was taken as derivational affix and not as the second term of a compound, given that in medieval Castilian from the 13th and 14th centuries the form used in the creation of adverbs (the borrowing -ment(e)) was not the same as the noun (the patrimonial miente). That is, the identity between the form used in the adverb and the noun mente on which the compound analysis is based didn't exist at that time.

It cannot be inferred from the information mentioned above, however, that we are dealing with a derivational phrasal affix. To decide between a lexical affix and a phrasal affix, the brief description above must be completed with some new facts. Although not conclusive, there are data that support the position defended here. I suggest, in fact, that in the 15th century not only was a process of replacement of patrimonial forms for a loan consolidated, but also that a change in the whole morphological system took place. This change is reflected in three distinct aspects that, taken independently, might appear to lack importance, but whose coincidence in time may be considered to indicate a deeper process.

Firstly, emphasis should be made of the brevity of time in which this replacement took place, since in just 50 years -mente became the dominant form, and in little over a century, pushed aside the other existing forms. There are no phonetic factors that justify this rapid replacement, given that the presumed coincidence with the affix -miento to form nouns was not applicable for forms that included $r$. Secondly, an observable change in the behaviour of adverbs in co-ordinated constructions should be taken into account. According to the findings of Karlsson's study (1981: 101-102), until the 15th century in the co-ordination of two adverbs - which, moreover, was a strange construction there often appeared two complete adverbial forms, although it was also possible to elide $-m(i) e n t(r) e$ in both the first and second adverbs. In other words, a vacillation was observed in the construction, although with a tendency to avoid elision. From the 15 th century onwards, it became the norm to eliminate -mente from all terms except the last one in such a way that, from the 16th century, it was very uncommon to come across the two complete forms. Thirdly, although not conclusive evidence, the fact that it was during this period when the orthography of -mente adverbs was generalised as a single word, since until then they had tended to be written as two separate words (see Karlsson 1981: 103-104), may be seen as a sign of that change. Whether -mente adverbs are written as one or two words is matter of convention, this convention tends to be a reflex of the intuitions that speakers have as to what is a word, in such a way that most processes of grammaticalization show this same tendency. For example, both the future tense - etymologically formed from the infinitive form followed by the present form of the verb haber ('to be') - and the conjunct formed by the 
verb + enclitic pronouns were written as two separate words in old Castilian, but are written as one word nowadays.

I believe that the coincidence in time of all these three phenomena is not due to chance, but in fact enables us to make a different interpretation. I propose that in the general state of things up to the 13th century, the language underwent a process of adverb formation from adjectives inherited from the evolution of a Latin syntagmatic construction. Simultaneously, it was a compound process, but had some particularities that made its existence difficult within the system: the second constituent of the compound was rather strange to the language, and the process had its own derivational productivity. For this reason, the replacement of the traditional forms for a suffix taken on loan was especially rapid, given that it allowed for a similar adverb formation system to be maintained, but better fitted to the structure of Castilian itself, the language in which the characteristics of this process were more similar to the characteristics of derivation. This change of a grammatical status, from compound to derivative, had an orthographic reflection on the new tendency to write the adverbs as a single word. Nevertheless, vestiges of the original Latin construction survived during the period - the most important of which was the internal inflection - so that the derivational affix taken from the Aragonese of Catalan was re-analysed as a derivational affix of a syntagmatic character, the consequence of which was a new norm for co-ordination in which elision was the only option that the language permitted.

This hypothesis is backed up by another historical phenomenon which, while independent of this process, displays a important parallelism. In the previous section, I argued in favour of the analysis of Spanish preverbal clitics as phrasal affixes. Just as I explained there, some linguistic facts coincide with the behaviour of the -mente adverbs and of the proclitic pronouns, especially in relation to elision in the co-ordinations. In a diachronic study of Castilian verbal pronouns, Fontana (1996) observes that the medieval system of clitics, functioning in a markedly different way to today's, remained stable until the 12 th and 13th centuries, from which time a process of re-analysis began that culminated in the 15th century and was the derivation of the current system, established only from then onwards. ${ }^{43}$ This meant the replacement of the medieval object clitic system by a new system in which they behaved as phrasal affixes took place between the 13th and 15th centuries, the same period of time that constituted the change described above in the mechanism for forming -mente adverbs. Put another way, until the 13th century Castilian lacked the mechanism of syntagmatic attachment: this was introduced into the system during

43. This study can be consulted for a more detailed discussion of this process. For the chronology of the change, see especially pages 62 and 63. 
the following two centuries and affected both the object clitics and the -mente adverbs alike.

\section{Conclusions}

The morphology of Spanish -mente adverbs has been a matter of long-standing debate. As noted, the construction originated as a noun phrase in Latin, and although the history of this formation is complex, vestiges of its original phrasal character still survive today. For this reason, the characterisation of these expressions from a morphological point of view is difficult: they show traits in common with both derivation and compounding. In this study I have defended an approach that takes this original phrasal character into account, and which is based on the concept of phrasal affix. According to the arguments presented above, -mente is a derivational phrasal affix that creates adverbs from adjective phrases in which the adjective is in its feminine form. Althouth it may seem surprising to posit a phrasal affix for a case which has traditionally been considered to involve word-level derivation morphology or compounding, the proposal explains some properties which escape description if these adverbs are considered as compounds, specifically the semantics of the affix, its internal morphological structure, the external syntax of the adverbs, and the resulting grammatical category. These aspects are satisfactorily resolved, in contrast, if I consider it as a derivational affix, but it is necessary to argue that it is a phrasal affix - and not an affix that operates in the lexicon - to explain why it appears after the adjective inflection and why it can be omitted in co-ordinations. Additionally, the analysis provides an explanation for data relating to use that have not been taken into account in prior studies.

\section{Institut Universitari de Lingüística Aplicada} Universitat Pompeu Fabra

\section{References}

Alarcos Llorach, Emilio (1951). Gramática estructural. Madrid: Gredos.

- (1970). Aditamento, adverbio y cuestiones conexas. In Estudios de gramática funcional del español, Emilio Alarcos Llorach, 219-253. Madrid: Gredos.

- (1994). Gramática de la lengua española. Madrid: Espasa-Calpe.

Alcina, Juan and José Manuel Blecua (1975). Gramática Española. Barcelona: Editorial Ariel.

Aronoff, Mark and Frank Anshen (1998). Morphology and the lexicon: Lexicalization and productivity. In The Handbook of Morphology, A. Spenser and A. Zwicky (eds.), 237-247. Oxford: Blackwell.

Bello, Andrés (1847). Gramática de la lengua castellana, Ramón Trujillo (ed.). Madrid: Arco/ Libros, 1988. 
Bosque, Ignacio (1987). Constricciones morfológicas sobre la coordinación. Lingüística Española Actual 9: 83-100.

- (1989). Las categorías gramaticales. Madrid: Editorial Síntesis.

Briz, Antonio (1998). El español coloquial. Situación y uso. Madrid: Arco-Libros, 2nd ed.

Chomsky, Noam (1970). Remarks on nominalization. In Readings in English Transformational Grammar, A. Jacobs and P. Rosembaum (eds.), 184-221. Waltham (Mass.): Ginn \& Co.

Corominas, Joan and José Antonio Pascual (1980). Diccionario crítico etimológico catellano e hispánico. Madrid: Gredos [referred to as DCECH].

Egea, Esteban Rafael (1979). Los adverbios terminados en -mente en el español contemporáneo. Bogota: Publications of the Instituto Caro y Cuervo.

- (1993). Restricciones lexicológicas en el uso de los adverbio en -mente. In La formación de palabras, Soledad Varela (ed.), 282-299. Madrid: Taurus.

Fernández, O. (1999). El pronombre personal. Formas y distribuciones. Pronombres átonos y tónicos. In Gramática descriptiva de la lengua española, Ignacio Bosque and Violeta Demonte (eds.), 1209-1273. Madrid: Espasa Calpe.

Fontana, Josep Maria (1996). Phonology and Syntax in the Interpretation of the Tobler-Mussafia Law. In Approaching Second: Second Position Clitics and Related Phenomena, Aaron L. Halpern and Arnold M. Zwicky (eds.), 41-83. Stanford: CSLI Publications.

Giacalone Ramat, Anna (1998). Testing the boundaries of grammaticalization. In The limits of grammaticalization, A. Giacalone Ramat and Paul J. Hooper (eds.). Amsterdam - Philadelfia: John Benjamins Publishing Company.

González García, Luis (1997). El adverbio en español. A Coruña: Universidade da Coruña.

Harris, J. W. (1991). La estructura silábica y el acento en español. Madrid: Visor. [Original title: Syllable Structure and Stress in Spanish: A Nonlinear Analysis. Boston: The Massachusetts Institute of Technology, 1983].

Hockett, Charles F. (1971). Curso de lingüística moderna. Buenos Aires: Editorial Universitaria de Buenos Aires. [Original title: A Course in Modern Linguistics. New York: The Macmillan Company, 1958].

Hooper, Paul J. and Elizabeth C. Traugott (1993). Grammaticalization. Cambridge: Cambridge University Press.

Karlsson, Keith E. (1981). Syntax and Affixation. The Evolution of MENTE in Latin and Romance, translation and adaptation by Emma Gregores and Jorge A. Suárez. Tubinga: Max Niemeyer Verlag.

Kovacci, Ofelia (1999). El adverbio. In Gramática descriptiva de la lengua española, Ignacio Bosque and Violeta Demonte (eds.), 705-786. Madrid: Espasa Calpe.

Lenz, Rodolfo (1935). La oración y sus partes. Madrid: Publicaciones de la RFE.

Miller, Philip H. (1991). Edge Inflection on the French NP. Santa Cruz (CA): University of California, Syntax Research Center, 91-3.

- (1992). Clitics and Constituents in Phrase Structure Grammar. New York: Garland.

Miranda, J. A. (1994). La formación de palabras en español. Salamanca: Ediciones del Colegio de España.

Nevis, J. A. (1985). Finnish particle clitics and general clitic theory. Unpublished doctoral thesis, Ohio State University.

O'Connor, Rob (2002). Clitics and Phrasal Affixation in Constructive Morphology. In Proceedings of the LFG02 Conference, Miriam Butt and Tracy Holloway King (eds.), CSLI Publications Online (http://csli-publications.stanford.edu/LFG/7/lfg02oconnor.pdf)

Pena, Jesús (1999). Partes de la morfología. Las unidades de análisis morfológico. In Gramática descriptiva de la lengua española, Ignacio Bosque and Violeta Demonte (eds.), 4305-4366.

Pensado, Carmen (1999). Morfología y fonología. Fenómenos morfofonológicos. In Gramática descriptiva de la lengua española, Ignacio Bosque and Violeta Demonte (eds.), 4423-4504. Madrid: Espasa Calpe. 


\section{Sergi Torner}

Piera, Carlos and Soledad Varela (1999). Relaciones entre morfología y sintaxis. In Gramática descriptiva de la lengua española, Ignacio Bosque and Violeta Demonte (eds.), 4367-4426.

Rainer, F. (1996). Inflection inside derivation: evidence from Spanish and Portuguese. In Yearbook of Morphology 1995, Geert Booij and Jaap van Marle (eds.), 83-91. Amsterdam: Kluwer Academic Publishers.

Real Academia Española (2001). Diccionario de la Lengua Española. Vigésima segunda edición. Madrid: Espasa-Calpe.

Riemsdijk, Henk C. van (1995). Clitics: A State of the Art Report. Tulbig University, Online doc-

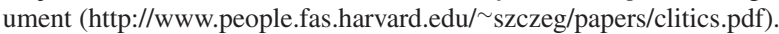

Rodríguez Ramalle, María Teresa (1999). Algunos aspectos de la sintaxis y la semántica de los adverbios y de ciertas expresiones adverbiales. Unpublished doctoral thesis, Universidad Autónoma de Madrid.

Seco, Manuel (1972). Gramática esencial del español. Madrid: Espasa-Calpe.

Seco, Manuel, Olimpia Andrés and Gabino Ramos (1999). Diccionario del Española Actual. Madrid: Aguilar.

Saporta, Soledad (1990). The status of Spanish forms in -mente. Hispanic Linguistics 4 (1): 181 183

Val Álvaro, José Francisco (1999). La composición. In Gramática descriptiva de la lengua española, Ignacio Bosque and Violeta Demonte (eds.), 4757-4841. Madrid: Espasa Calpe.

Varela Ortega, Soledad (1990). Fundamentos de morfología. Madrid: Editorial Síntesis.

Villalva, Alina (2000). Estructuras Morfológicas. Unidades e Hierarquias nas Palavras do Português. Lisboa: Fundação Gulbenkian.

Zagona, Karen T. (1990). Mente adverbs, compound interpretation and the projection principle. Probus 2 (1): 1-30.

Zwicky, Arnold M. (1987). Suppressing the Zs. Journal of Linguistics 23: 133-148.

Zwicky, Arnold M. and Pullum, Geoffrey K. (1983). Cliticization vs. Inflection: English n't. Language 59 (3): 502-513. 